\title{
RESISTANCE RATIO ASSESSMENT TO SEVERAL BIOINSECTICIDES IN COTTON LEAFWORM, Spodoptera littoralis AT DIFFERENT GOVERNORATES IN EGYPT
}

Singab, M. ${ }^{1}$; A. S. El-Hefny ${ }^{2}$ and M. K. M.EL-Hadek ${ }^{1}$

1- Central Agricultural Pesticide Laboratory, Agricultural Research Center, Dokki, Egypt

2- Plant Protection Research Institute, Agricultural Research Center, Dokki, Egypt

\begin{abstract}
This study aimed mainly to estimate the resistance of the cotton leafworm Spodoptera littoralis to several bioinsecticides (Spnitor, Protecto, Dipel DF, Dipel 2X, Agrine and Radical) throughout determining the resistance ratio values. Among all the tested bioinsecticides, Radical had the highest resistance ratio in the four Governorates, while, Spnitor had the lowest resistance ratio in all these Governorates. The relative toxicity of these bioinsecticides to $S$. littoralis was also determined. The results clearly indicated that Radical was the most toxic bioinsecticides in all four field strains followed by Spnitor, while the other bioinsecticides were the least toxic action.

Keywords: Spodoptera littoralis (Boisd.), bioinsecticides.
\end{abstract}

\section{INTRODUCTION}

The Egyptian cotton leafworm, Spodoptera littoralis (Boisd.) is one of the most notorious and destractive phytophagous insect pests in Egypt, not only to cotton, but also to other field crops and vegetables (Kandil et al., 2003). These caterpillars are very polyphagous, causing important economic losses in both greenhouses and open field on a broad range of ornamental, industrial and vegetable crops. Besides many populations have acquired resistance towards most insecticide groups (Alford, 2000). During the last two decades research has been made for new and non-traditional control agents effective against this pest since resistance has been recorded for most conventional insecticides (Rashwan et al., 1992). Spinosad (as represented by spinotor) is a more recent commercial insecticide derived from metabolites of actinomycete bacterium, Saccharopolyspora spinosa (Mertz and Yao, 1990). The active ingredient is composed of Spinosyn A and Spinocyn D, have strong insecticidal activity (Thompson et al., 1997) with low level of mammalian toxicity and little toxicity to non-target insects (Bret et al., 1997). Spinosad has been classified as a bioinsecticide (Copping and Menn, 2000). It was selected as a candidate natural product insecticide since is active as ingestion and contact (Sparks et al., 1998). Traditional insecticides known as an effective tool in controlling insects; but they have some adverse effects on non-target organisms and on the environment. In addition, insect resistance was developed against some of those insecticides.

The bioinsecticides have become important an alternative tool that may be included in insect management programs. The entomopathogenic bacteria, Bacillus thuringiensis, represent a good example for the current 
method of biological control (Matter, 1991). B. thuringiensis based formulations have been used over many years to control lepidopterous pests on vegetable, fruits, field crops, forest and stored grain under more varied environmental conditions than any other microbial (Ignoffo and Gregory, 1972).

The aim of this study is to determine the resistance ratios of the second instar larvae of the cotton leafworm S. littoralis against certain bioinsecticides in some Egyptian Governorates. Therefore, presents which one of bioinsecticides could be used against this pest .The most effective tested insecticide could be used for controling such insect.

\section{MATERIALS AND METHODS}

Insects:

Susceptible insect strain:

Insects were obtained from a culture at the Central Agricultural Pesticides Laboratory, Agricultural Research Center, Dokki, Giza in which they were reared on fresh leaves of castor bean leaves without any insecticidal pressure. The culture was reared under laboratory conditions (25 $\pm 2^{\circ} \mathrm{C}$ and $65 \pm 5 \%$ R.H.).

\section{Field strains:}

The cotton leafworm, $S$. littoralis egg-masses were collected from four different Governorates; Fayoum, Menofia, Sharkia and Dakahlia. All the egg-masses were collected during June 2012 growing season. Then transferred to the laboratory, kept until hatching at $25 \pm 2^{\circ} \mathrm{C}$ and $65 \pm 5 \%$ R.H.). The larvae were kept in plastic pots and reared on fresh leaves of castor bean until they reached the $2^{\text {nd }}$ larval instar.

\section{Bioinsecticides used:}

Six different bioinsecticides were used in this study. Four of them were entomopathogenic bacteria, B. thuringiensis, Dipel DF $6.4 \%$ WG, Protecto 9.4\% WP, kurstaki, Dipel 2X 6.4\% WP, Agrine 6.5\%WP and the other two remainings are Spinosad, (Spnitor 24\% SC) and Emamectin benzoate (Radical $0.5 \%$ EC).

\section{Bioassay studies:}

Laboratory experiments were conducted to study the toxic effect of determining $\mathrm{LC}_{50}$ values at $5 \%$ confidence limits and slope regression line. Mortality data were corrected according to Abbot (1925), and then subjected to statistical analysis by the method of Finney (1952).

Five serial concentrations were prepared for each bioinsecticides, and for each concentration 40 individuals of the $2^{\text {nd }}$ larval instar were chosen, divided into four replicates (10 larvae / replicate). All larvae were starved for 4 hours before offering the treated food to assure rapid ingestion. Fresh cleaned castor bean leaves were dipped in the desired product solution for about two minutes then they were left in shade for 10 minutes to dry. The starved larvae were gently transferred on the treated leaves in plastic cups. The plastic were fixed tightly, the larvae were offered untreated castor bean leaves after 48 hours. Mortality was recorded 72 hours after treatment. 
Resistance Ratio(RR) estimations:

Resistance ratio to all the used bioinsecticides were calculated for $S$. littoralis larvae which were collected from the field of four Governorates in relation to susceptible strain according to the following equation:

Resistance ratio $(R R)=L C_{50}$ for the field strain $/ L_{50}$ for the susceptible strain

Toxicity index calculation:

Toxicity index for all tested bioinsecticides were calculation according Sun 1950 by following equation;

Toxicity index $=\mathrm{LC}_{50}$ for most effective compound $/ \mathrm{LC}_{50}$ for lest effective compound

\section{RESULTS AND DISCUSSION}

In Table (1) and Fig.1, the $\mathrm{LC}_{50}$ and relative toxicity (TI) values and resistance ratios (RR) for the tested bioinsecticides used against the cotton leafworm, S. littoralis were calculated for both susceptible and field strains collected from four Governorates namely Fayoum, Menofia, Sharkia and Dakahlia in the cotton season 2012.

. It is clear from the results shown in Table (1), Radical had higher levels of resistance than that of the other bioinsecticides tested in all four field strains, where RR ranged from as low as 8.6-fold in Dakahlia strain to as high as 13.1 -fold in Sharkia strain. In contrast to results obtained with Radical, all tested field strains were high sensitive to Spintor, where RR ranged between 0.6-0.9-fold.

As for B.thuringiensis, Diple-DF, the resistance levels were low but varied among field strains, where the lowest level was in sharkia (1.4-fold) followed by Menofia (1.8-fold), Dakahlia (2.4-fould), while the highest level was in Fayoum (3.5-fold). With regards to the another formulation of B.thuringiensis, Protecto, the same pattern of resistance levels to Dipel-DF was also observed with Protecto, where levels of resistance ranged between 1.6-4-fold, but the lowest level was found in Fayoum followed by Menofia 2.2-fold, Sharkia 3.1-fold and Dakahlia 4-fold.

As for the formulation of B.thuringiensis Kurstaki, the resistance levels of Diple-2X varied from one region to another, where resistance levels were 1.4, 2.9, 3.5 and 4-fold for Dakahlia, Sharkia, Fayoum and Menofia, respectively. The other related B.t. Kurstaki, Agrine, all field strains exhibited moderate levels of resistance which ranged from as low as 4.0 - fold in Fayoum strain to as high as 5.6- fold in Menofia strain.

The $\mathrm{LC}_{50}$ values and toxicity indexes (TI) to bioinsecticides in four field strains are presented in table (1) and illustrated in fig. 1 . The results clearly indicated that Radical $L_{50}$ values of $0.106,0.136$ and $0.163 \mathrm{ppm}$ in Dakahlia, Menofia, Fayoum and Sharkia, respectively. Spnitor came next on the list of toxicity, where the toxicity index value was $1.7,1.5,2.2$ and $1.8 \%$ of the toxicity of Radical in Dakahlia, Menofia, Fayoum and Sharkia, respectively. The other bioinsecticides were less toxic than that of Radical. Among four field strains, the toxicity index ranged between $0.1-0.4 \%, 0.1$ $0.3 \%, 0.1-0.2 \%$ and $0.1-0.2 \%$ for Protecto, Dipel-DF, Dipel $-2 \mathrm{X}$ and Agrine, respectively. 
Singab, M. et al. 
The same trend was also observed on the susceptible strain as shown also in table (1). The results indicated that Radical was the most effective bioinsecticides $(100 \%)$ with LC $_{50}$ value of $0.0124 \mathrm{ppm}$ followed by Spintor $(0.12 \%)$, while the other bioinsecticides were less toxic as compared with Radical, where the toxicity index ranged from $0.07-0.03 \%$

As mentioned above, it is clearly showed that Radical was the most effective bioinsecticides tested in four field strains although Radical exhibited high levels of resistance, while Spnitor came next on the list of toxicity (toxicity index ranged between $1.5-2.2 \%$ of the toxicity of Radical but all field strains showed high sensitive to its action. The other bioinsecticides showed low or moderate levels of resistance with low toxicity as compared with Radical.

Finally, it is hope that the present results will aid in a better control of the cotton leafworm $S$. littoralis

This data agreed with Hilal and Oktay (2005), who found that the field strain of $S$. littoralis was approximately 4.4 -fold more insensitive to spinosad than the susceptible strain, the difference might be due to the differential susceptibility of strains and intensive insecticide selection pressure. On the other hand, Temerak (2007), indicated that Radiant SC12\% was 5 and 7 times stronger than spintor SC24\% against the field and laboratory strains of S. littoralis, respectively. Also, Elbarky et. al., (2008), found that the effect of different concentrations of Radiant SC12\% (Spinetoram) as a bioinsecticide against larvae of $S$. littoralis (Boisd.) in laboratory and recommended doses in field showed $100 \%$ mortality of entire hatched egg-masses.

Korrat et. al. (2012), showed that S. littoralis (Boisd.) under laboratory conditions, after 3 days of the treatment, emamectin benzoate was the most effective insecticide followed by chlorfluazuron and profenofos and finally spinosad showed the lowest toxic effect.

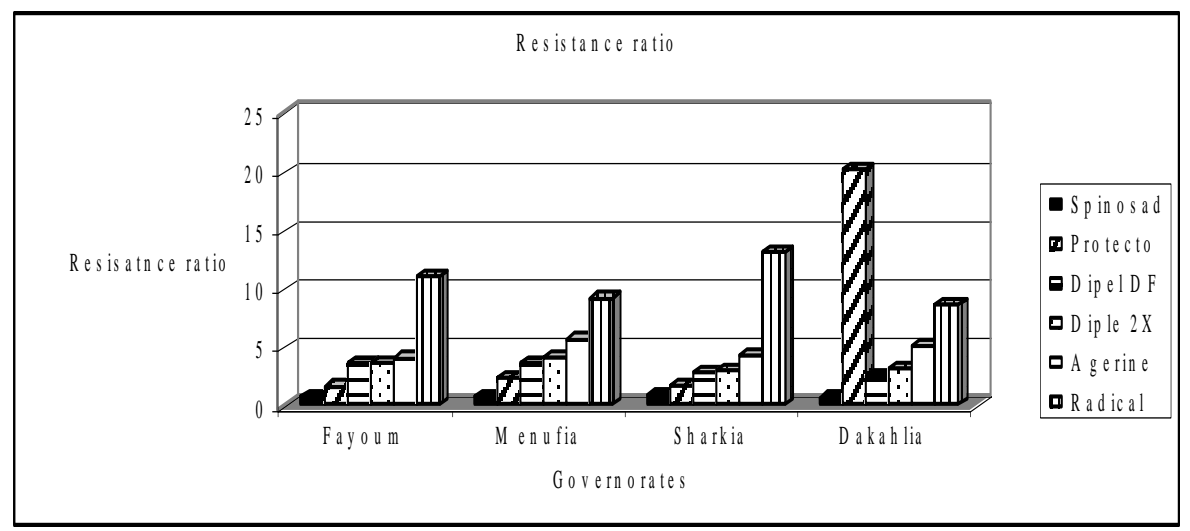

Fig. 1: Resistance ratio for the tested six bioinsecticides in each Governorate 


\section{REFERENCES}

Abbot, W.S. (1925). A method of computing the effectiveness of insecticides. J. Econ. Entomol, 18: 265 - 267.

Alford, D. V. (2000). Pest and disease management hand book British crop protection council, Blackwell Sceience, Oxoford, 615pp.

Bret, B. L.; Larson, L. L. and Schoonover, J.R. (1997). Biological proporeties of spinosad. Down to earth, 52:1, 6-13.

Copping, L. G. and Menn, J. J. (2000). Biopesticide: a review of their action, applications and efficacy. Pest manag. Sci. 56, 651-676

Elbarky, Nehad M.; Dahi, H. F. and El-Sayed, Y. A. (2008). Toxicological evaluation and biochemical impacts for radient as a new generation of spinosyn on Spodoptera littoralis (Boisd.) larvae. Egypt. Acad. J. biolog. Sci., 1(2): 85- 97.

Finney, M.D.J., (1952): Probit Analysis 3rd .Cambridge Univ. Press, London, pp: 333.

Hilal AYDIN, M. and Oktay G. R. (2005). The Efficacy of Spinosad on Different Strains of Spodoptera littoralis (Boisduval) (Lepidoptera: Noctuidae). Department of Plant Protection, Faculty of Agriculture, Ankara University 08.06

Ignoffo, C. and B. Gregory (1972). Effect of Bacillus thuringiensis B-toxin on larval maturation, adult longevity, fecundity and egg viability in several species of Lepidoptera. Environ. Entomol., 1: 269 - 272.

Kandil, M. A.; Abdel-Aziz N.F. and Sammour E.A. (2003). Comparative toxicity of chlorofluazron and leufenuron against cotton leafworm, Spodoptera littoralis (Boisd.). Egypt. J. Agric. Res. NRC, 2:645-661.

Korrat, E.E.E; Abdel-monem, A.E.; Helalia, A.A.R and Khalifa, H.M.S. (2012). Toxicological study of some conventional and nonconventional insecticides and their mixtures against cotton leafworm, Spodoptera littoralis (Boisd.) (Lepidoptera: Noectudae). Annals of Agricultural Science 57(2), 145-152.

Matter, M.M. (1991). Bacillus thuringiensis and environmental safety, Int. Workshop on Bacillus thuringiensis and its application in developing countries. NRC. Cairo, Egypt, 4 - 6 Nov.

Mertz, P.P. and Yao R.C. (1990). Saccharopolyspora spinosa sp.nov. isloated soil collected in a sugarrum still. Internal F. Sust Bacterial, 40: 34-39.

Rashwan, M. H. ; Elbaramawy, Z. A.; El-Sheikh A. E. and Radwan, H. S. A. (1992). The onest of organophosphate and carabamate resistance among lower Egypt population of the cotton leafworm Spodoptera littoralis (Boisd).Bull. Ent. Soc. Egypt, econ. Ser. 19: 211-220

Sparks, T.C. ; Thompson, G.D.; Kirst, H. A.; Hertlein M.B. Larson, L.L.; Worden, T. V. and Thibault, S.T. ( 1998). Biological activity of the spinosyns, new fermentation derived insect control agents on tobacco budworms larvae (Lepidoptera- Noctuidae). J. Econom. Entomol., 91:1277-1283. 
Sun, Y. P. (1950). Toxicity index-an improved method of comparing the relative toxicity of insecticides. J. Econ. Entomol. 43: 45-53

Temerak, S. A. (2007). Susceptibility of Spodoptera littoralis to old and new generation of spinosyn products in five cotton Governorates in Egypt. Resistance Pest Management Newsletter 16 (2): 18-21.

Thompson, G. D.; Michel, K. H.; Yao R. C.; Mynderse J. S.; Mosbury, C. T.; Worden, T. V.; Chio, E. H.; Sparks, T.C. and Hutchins, S.H. (1997). The discovery of Saccaropolyspora spinosa and a new class of insect control products. Down to Earth, 52(1): 1-5.

تقديرمسـتويات المقاومـة لعـدة مبيـات حيويـة فـى دودة ورق القطن لمحافظـات

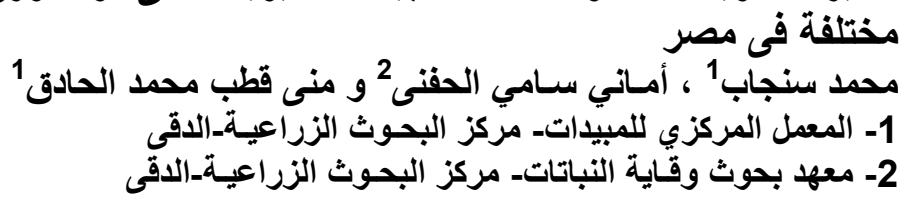

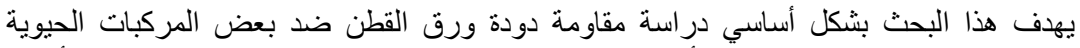

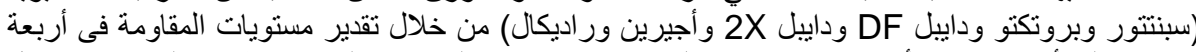

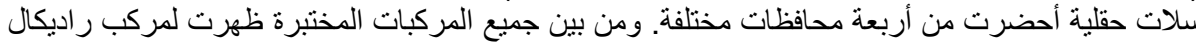

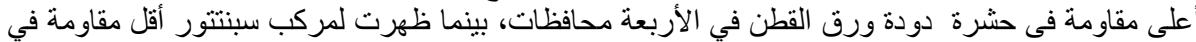

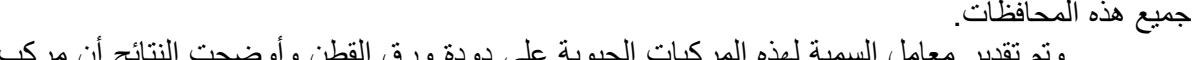

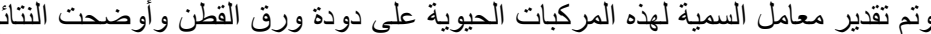

الراديكال كان أكثر أكثر المبيدات الحيوية سمية فى الأربعة سلالات الحقلية يلية مركب سبنيتئور، بينما كانت

بقية المركبات الحيوية المختبرة أقل سمية. 

Table (1): Resistance ratio and toxicity index to several bioinsecticides in the cotton leafworm collected from four

\begin{tabular}{|c|c|c|c|c|c|c|c|c|c|c|c|c|c|c|c|c|c|c|c|}
\hline \multirow[b]{2}{*}{ Bioinsecticide } & \multicolumn{3}{|c|}{ Susceptible Strain } & \multicolumn{4}{|c|}{ Fayoum } & \multicolumn{4}{|c|}{ Menofia } & \multicolumn{4}{|c|}{ Sharkia } & \multicolumn{4}{|c|}{ Dakahlia } \\
\hline & slope & $\begin{array}{l}\mathbf{L C}_{50} \\
(\mathrm{ppm})\end{array}$ & $\mathrm{TI}^{* *}$ & slope & \begin{tabular}{|c|}
$\begin{array}{c}\mathbf{L C}_{50} \\
(\mathrm{ppm})\end{array}$ \\
\end{tabular} & $\mathbf{R R}^{*}$ & $\mathrm{TI}^{\star \star}$ & slope & \begin{tabular}{|c|}
$\begin{array}{c}\mathbf{L C}_{50} \\
(\mathrm{ppm})\end{array}$ \\
\end{tabular} & $\mathbf{R R}^{*}$ & $\mathrm{TI}^{\star \star}$ & slope & \begin{tabular}{|c|}
$\begin{array}{c}\mathbf{L C}_{50} \\
(\mathrm{ppm})\end{array}$ \\
\end{tabular} & $\mathbf{R R}^{\star}$ & $\mathrm{Tl}^{\star \star}$ & slope & \begin{tabular}{|c|}
$\begin{array}{c}\mathbf{L C}_{50} \\
(\mathrm{ppm})\end{array}$ \\
\end{tabular} & $\mathbf{R R}^{*}$ & $\mathrm{TI}^{* *}$ \\
\hline $\begin{array}{c}\text { Spinosad, } \\
\text { (Spnitor 24\% SC) }\end{array}$ & 1.08 & 10.50 & $0.12 \%$ & 2.87 & 6.26 & 0.6 & 2.2 & 0.73 & 7.70 & 0.7 & $1.5 \%$ & 2.19 & 9.05 & 0.9 & $1.8 \%$ & 1.82 & 6.16 & 0.6 & $1.7 \%$ \\
\hline $\begin{array}{c}\text { Bacillus } \\
\text { thuringiensis } \\
9.4 \% \text { WP) } \\
\text { (Protecto }\end{array}$ & 1.61 & 20.37 & $\% 0.06$ & 1.13 & 31.54 & 1.6 & $0.4 \%$ & 2.21 & 40.28 & 2.2 & $0.3 \%$ & 2.68 & 63.45 & 3.1 & $0.3 \%$ & 2.15 & 81.40 & 4 & $0.1 \%$ \\
\hline $\begin{array}{c}\text { Bacillus } \\
\text { thuringiensis } \\
\text { (Dipel DF 6.4\% } \\
\text { WG) } \\
\end{array}$ & 0.80 & 40.45 & $\% 0.03$ & 1.20 & 141.71 & 3.5 & $0.1 \%$ & 3.60 & 73.27 & 1.8 & $0.2 \%$ & 1.81 & 57.37 & 1.4 & $0.3 \%$ & 2.94 & 95.93 & 2.4 & $0.1 \%$ \\
\hline $\begin{array}{c}\text { Bacillus } \\
\text { thuringiensis } \\
\text { (Dipel } 2 X 6.4 \% \text { WP) }\end{array}$ & 1.72 & 39.47 & $\% 0.03$ & 1.96 & $\mid 138.99$ & 3.5 & $0.1 \%$ & 4.02 & $|158.64|$ & 4 & $0.1 \%$ & 1.62 & 113.50 & 2.9 & $0.1 \%$ & 1.52 & 55.90 & 1.4 & $0.2 \%$ \\
\hline $\begin{array}{c}\text { Bacillus } \\
\text { thuringiensis } \\
\text { Agrine } 6.5 \% \text { WP }\end{array}$ & 0.99 & 18.25 & $\% 0.07$ & 1.41 & 72.51 & 4 & $0.2 \%$ & 5.58 & 102 & 5.6 & $0.1 \%$ & 1.82 & 77.05 & 4.2 & $0.2 \%$ & 1.86 & 101.01 & 5.5 & $0.1 \%$ \\
\hline $\begin{array}{c}\text { Emamectin } \\
\text { benzoate } \\
\text { (Radical } 0.5 \% \text { EC) }\end{array}$ & 1.11 & 0.0124 & $\% 100$ & 2.03 & 0.136 & 11 & $100 \%$ & 9.11 & 0.113 & 9.1 & $100 \%$ & 1.87 & 0.162 & 13.1 & $100 \%$ & 2.29 & 0.106 & 8.6 & $100 \%$ \\
\hline
\end{tabular}

$\mathbf{R R}^{\star}($ Resistance ratio $)=\mathbf{L C}_{50}$ of the field strain $/ \mathbf{L C}_{50}$ of the laboratory strain

$\mathrm{TI}^{\star \star}$ (Toxicity index) $=\mathrm{LC}_{50}$ for most effective compound $/ \mathrm{LC}_{50}$ for lest effective compound 